\title{
Perancangan Sistem Portal Program Studi dengan Menggunakan Framework Laravel Dan Database Postgresql
}

\author{
Rio Ariestia Pradipta ${ }^{1}$, Mahendra Pratama ${ }^{2}$, Meizano Ardhi Muhammad ${ }^{3}$, Mona Arif Muda ${ }^{3}$ \\ Program Studi Teknik Informatika Universitas Lampung, Bandar Lampung \\ J1. Prof. Sumantri Brojonegoro No.1 Bandar Lampung 35145 \\ ${ }^{1}$ rio.ariestia@eng.unila.ac.id \\ 2 mahendra.pratama15@eng.unila.ac.id \\ ${ }^{3}$ meizanodeng.unila.ac.id \\ ${ }^{4}$ mona.batubara@eng.unila.ac.id
}

Intisari - Program studi Teknik Informatika Universitas Lampung memiliki beberapa sistem informasi untuk menunjang kegiatan administrasi yang mempermudah aktifiitas yang dilakukan oleh mahasiswa, dosen dan juga bagian administrasi. Keseluruhan sistem tersebut berfungsi untuk mempermudah kegiatan administrasi, dokumentasi serta untuk pengembangan aktifitas strategis yang direncanakan dan akan dilaksanakan oleh program studi pada masa yang akan datang. Untuk mempermudah terjadinya integrasi pada seluruh sistem informasi yang terdapat di program studi maka diperlukan sebuah sistem yang berfungsi sebagai wadah untuk mengintegrasikan keseluruhan sistem yang ada. Tujuan dari penelitian ini adalah memberikan solusi pada program studi Teknik Informatika dalam melakukan integrasi informasi dari beberapa sistem informasi yang berjalan ke dalam sebuah sistem portal berbasiskan web. Penelitian ini dilakukan dengan menggunakan metode pengembangan sistem secara local dimana pengembangan software dilakukan dengan alur Rapid Application Development yang termasuk di dalamnya perancangan sistem menggunakan usecase diagram, class diagram dan struktur navigasi portal. Bahasa pemrograman dalam pengembangan sistem adalah PHP dengan framework Laravel dan menggunakan database PostgreSQL. Metode blackbox digunakan dalam melakukan pengetesan dari sistem portal yang telah dirancang untuk mengetahui kesesuaian antara rancangan dengan sistem portal terbangun. Hasil yang didapatkan adalah kesesuaian antara rancangan dengan portal yang siap untuk diimplementasikan sebagai sebuah sistem informasi.

Kata kunci — Laravel, Perancangan Portal, PostgreSQL, Sistem Informasi.

Abstract - University of Lampung Informatic Engineering study program have various information systems to facilitate administrative activity for student, lecturer and administration helpdesk. All systems function to facilitate administrative activities, documentation and to develop strategic activities that planned and will be carried out by study program in the future. To help integrating whole systems the study program need a system that functions as a place to integrate all existing systems. The objective of our research are provide solution for Informatic Engineering study program to integrate information from various existing information systems into a web-based portal system. This research was conducted using a local system development method with Rapid Application Development flow which include system design using usecase diagrams, class diagrams, and portal navigation structures. For system development using PHP with Laravel framework and PostgreSQL for database. Blackbox method are used for testing designed system, to find out compatibility between the design and the built portal system. The result obtained are the compatibility between the design and the portal that is ready to be implemented as a running information system. Keywords - Laravel, Portal Design, PostgreSQL, Information System.

\section{PENDAHULUAN}

Sistem informasi berbasis website saat ini berkembang dalam tahap yang sangat cepat. Menampilkan bermacam bentuk informasi kepada para pengguna dengan sangat cepat. Informasi yang ditampilkan dapat memberikan berbagai manfaat dalam mengembangkan kemampuan, pengetahuan bahkan menjadi penentu langkah strategis para pengambil kebijakan pada suatu organisasi. Program studi Teknik Infomatika memiliki beberapa sistem ini formasi yang bekerja dengan fungsi membantu berjalannya kegiatan administratif yang dilaksanakan di program studi. Beberapa sistem yang berjalan tersebut menjalankan fungsi administrasi untuk memudahkan mahasiswa, dosen dan bagian admin Teknik Informatika dalam melaksanakan kegiatan administrasi sebagai pendukung kegiatan belajar dan mengajar. 
Sistem informasi yang sudah berjalan tersebut masih berjalan secara terpisah, sedangkan informasi dan hasil yang diperoleh pada setiap sistem sangat bermanfaat untuk pengembangan program studi dalam mengambil keputusan strategis pada masa yang akan datang. Namun pengambilan keputusan ini perlu sistem yang saling terkait.

Pengambilan keputusan menjadi satu hal yang dibutuhkan dengan berdasarkan pada informasi yang didapatkan dari semua sistem pendukung. Sebagai upaya untuk menggabungkan dan mengintegrasikan informasi tersebut adalah dengan menyediakan sebuah wadah yang menampung semua informasi dan dapat membantu pengambilan keputusan yang baik untuk pengembangan program studi Teknik Informatika.

Rumusan masalah yang ada pada penelitian ini adalah "Bagaimana sistem dengan berbasiskan portal yang dibutuhkan oleh Program Studi Teknik Informatika Universitas Lampung untuk penunjang pengambilan keputusan?" dengan memberikan Batasan untuk portal ada berbasis web dengan mengintegrasikan semua sistem informasi yang ada pada program studi Teknik Informatika.

Tujuan dari penelitian ini adalah membuat sebuah rancangan sistem portal program studi dengan mengambil konten berupa informasi dari sistem informasi yang sudah ada sebagai informasi yang bisa dipakai sebagai bahan untuk pengambilan keputusan.

Penelitian Terkait

Ajey Kumar Pathak, dkk pada penelitiannya menampilkan data terintegrasi dari beberapa sumber database tentang Genomic Ikan yang digabung dengan data tambahan mereka lalu diintegrasi dan ditampilkan pada sebuah portal hasil penelitian mereka bernama FisOmics. Portal tersebut dibangun dengan bahasa pemrograman PHP dan database mySql. Dengan portal fisomics memudahkan peneliti untuk melakukan query data genomic dari berbagai macam database hanya melalui satu portal saja. [9]

Jaroslav Havlicek, Zdenek Havlicek, Jiri Vanek dan Edita Silerova pada penelitiannya membuat sebuah portal yang digunakan untuk pengambilan keputusan pada sistem pertanian di Republik Ceko. Portalnya dibuat dengan menyertakan semua prinsip Decision Support System. Portalnya membantu para petani dan entrepreneur untuk mengambil keputusan secara dinamis dan flexibel pada bidang pertanian. [3]

Oktaviani melakukan penelitian merancang sebuah Portal berbasi web untuk menampilkan informasi tentang sebuah Seminar Nasional. Pada penelitiannya Oktaviani menggunakan metodologi waterfall yang banyak digunakan untuk merekayasa perangkat lunak dengan melakukan analisa kebutuhan sistem yang terdiri dari kebutuhan perangkat lunak hingga kepada perangkat keras, melakukan perancangan sistem, membangun aplikasi dengan tools, dan melaksanakan ujicoba kepada para pengguna. [7]

Pada penelitian yang dilakukan oleh Agi Candra Bramantia yang mendirikan sebuah lama web portal yang dapat menjadi wadah sistem informasi akademik beberapa perguruan tinggi yang tersimpan pada suatu yayasan. Melakukan analisa dan pembuatan desain web portal sistem informasi akademik pada beberapa perguruan tinggi yang memiliki basis data terdistribusi dalam satu yayasan. [1]

Siti Nurhayati dan Mufid Nilmada melakukan penelitiannya dalam membangun sebuah laman situs portal berita untuk kampus Universitas Gunadarma. Pembuatannya adalah menggunakan framework PHP CodeIgniter dan juga penerapan menggunakan basis data MySql. Portal tersebut digunakan sebagai sarana untuk mengetahui informasi terkait kampus yang bisa diketahui oleh seluruh civitas kampus. [6]

Alan Kristiawan Santoso dalam penelitiannya melakukan pembuatan rancangan dan membuat realisasi pada lama web portal Jurusan Teknik Elektro Universitas Maranatha dengan menggunakan PHP framework Laravel dan pada bagian perancangannya menggunakan Unified Modelling Language dengan software rational rose. Portal yang dibuat menampilkan informasi yang dibutuhkan untuk keperluan publikasi kepada masyarakat. [12] 
Pada penelitian yang dilakukan oleh Farizan Luthfi dalam pembuatan rancang bangun modul back-end artikel website bisnisbisnis.id menggunakan framework Laravel. [4]

Portal adalah sebuah sarana untuk melakukan penyatuan bermacam jenis informasi dan aplikasi yang tersebar baik berada di internal maupun external institusi. Sehingga semua informasi dapat disatukan dan diintegrasikan dari internet kedalam sebuah sistem informasi untuk menjadi solusi yang efektif dan efisien untuk dapat menjembatani berbagai sistem, format aplikasi yang berbeda. Dimana menjadi sarana penghubung yang tanpa batas dan tanpa gangguan yang terjalin diantara stakeholder, hingga antar perusahaan yang berbeda. [13]

Pada penelitian ini akan menggunakan metode Rapid Application Development dimana RAD adalah merupakan sebuah proses yang ada dalam melakukan pengembangan sistem maupun perangkat lunak dengan metode sekuensial linier model yang memberikan penekanan pada siklus pengembangan yang dapat dilakukan dalam tempo yang singkat dan menggunakan pendekatan konstruksi berbasis komponen. Pada model ini requirement atau persyaratan harus diketahui dan didefinisikan dengan baik, dan lingkup proyek terbatas. Proses RAD dapat memungkinkan tim pengembangan untuk membuat sistem yang berfungsi penuh dengan periode waktu yang sangat singkat. Model ini mengasumsikan persyaratan untuk tetap tidak berubah selama proyek dikerjakan. [2]

Hasil perancangan dilakukan pengetesan. Menggunakan metode blackbox dimana metode ini dapat digunakan untuk mengetahui kesesuain antara rancangan dengan hasil pembangunan sistem. Adella Rosalina, dkk melakukan penelitian dengan melakukan pengujian blackbox teknik equivalence partitions pada sistem informasi berbasiskan web sehingga dapat mengetahui apakah sistem yang dibuat masih terdapat kesalahan pada pembuatannya. [10]

Penelitian tentang testing dengan metode blackbox juga dilakukan oleh Ni Putu Linda Santiari, dkk. Dimana pada penelitiannya melakukan pengetesan pada sebuah sistem informasi reservasi lapangan futsal berbasis website. Teknik blackbox yang digunakan boundary value analysis untuk melihat kualitas dari perangkat lunak apakah sudah sesuai dengan fungsi yang diharapkan. [11]

\section{METODOLOGI}

Penelitian akan dilakukan dengan menganalisa dan mengumpulkan kebutuhan dari sistem yang akan dibuat, membuat desain sesuai dengan kebutuhan yang sudah dikumpulkan, kemudian melakukan analisa perancangan sistem portal prodi berbasis web. Analisa kebutuhan dilakukan dengan mewawancara user untuk mendapatkan kebutuhan yang sesuai untuk diterapkan pada sistem.

Dalam penelitian ini akan digunakan peralatan atau perangkat berupa :

1. 1 unit laptop dengan spesifikasi :
a) RAM $8 \mathrm{~GB}$
b) Processor intel core i7
c) SDD 250GB
2. Apache Server
3. Database PostgreSQL
4. PHP
5. Framework Laravel

Sistem portal program studi teknik informatika ini akan menggunakan beberapa fase tahapan dalam pengerjaannya. Dimana pelaksanaannya akan menggunakan metode Rapid Application Development. [2]

\section{Tahap 1 : Perencanaan}

Pada tahap ini dilakukan wawancara pada pengelola administrasi program studi. Diperoleh informasi ketika melaksanakan tugas administrasi pendataan status keaktifan maupun kegiatan mahasiswa pada program studi masih dilakukan secara manual dengan menggunakan program spreadsheet yang disimpan dalam beberapa file yang terpisah. Menunjukan bahwa proses ini membutuhkan sebuah sistem yang dapat membuat kegiatan administrasi tercatat secara lebih baik, sehingga data dapat dengan mudah disimpan maupun ditampilkan kembali dimasa yang akan datang ketika dibutuhkan untuk keperluan administrasi. 
Keterhubungan data yang saling terintegrasi juga menjadi hal yang diperlukan selain membuat administrasi pencatatan yang tersistem. Dengan membuat data saling terintegrasi mengurangi kemungkinan adanya data ganda. Pelaporan. Informasi yang digunakan adalah data Dosen, Mahasiswa, Kegiatan Mahasiswa. Selain itu integrasi juga memudahkan pengembangan sistem administrasi program studi. Fitur yang akan tampil pada sistem portal yang dirancang secara singkat ditunjukkan pada tabel 1 .

\section{Tabel 1. Fitur Sistem}

\begin{tabular}{cll}
\hline ID & \multicolumn{1}{c}{ Pelaku } & \multicolumn{1}{c}{ Kegiatan } \\
\hline S-01 & $\begin{array}{l}\text { Pengguna/ } \\
\text { User }\end{array}$ & $\begin{array}{l}\text { Melakukan kegiatan } \\
\text { administrasi pada portal }\end{array}$ \\
\hline S-02 & Sistem & $\begin{array}{l}\text { Menampilkan Data dan juga } \\
\text { kegiatan Mahasiswa }\end{array}$ \\
\hline
\end{tabular}

Use case digunakan untuk meggambarkan pola kegiatan atau kebiasaan yang terjadi pada sebuah sistem portal yang dirancang. Dengan tujuan untuk penggambaran skenario statis interaksi dari kejadian antara aktor yang terlibat dengan kegiatan yang dilakukan dalam sebuah sistem berjalan [5]. Sehingga dapat menjelaskan fungsi apa saja yang dilakukan oleh sistem maupun oleh subsistem, siapa saja yang terlibat dan memiliki hak dalam menggunakan fungsi tersebut :

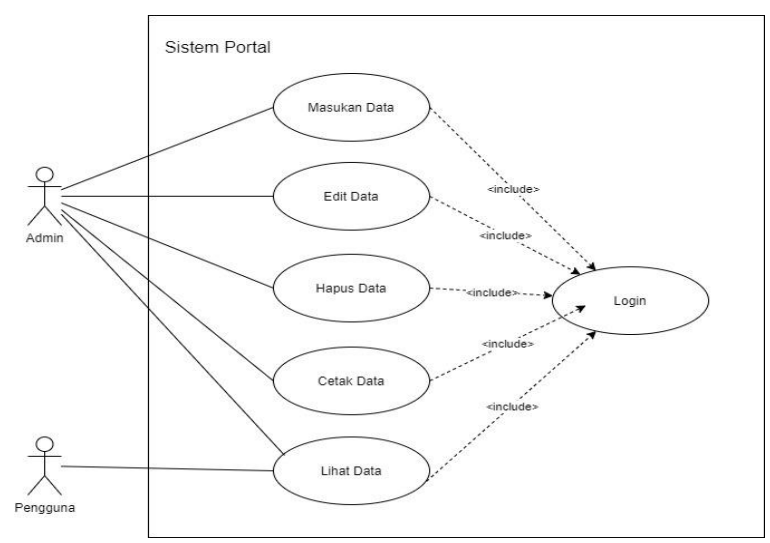

Gbr. 1 Use Case Diagram

Detail penjelasan Use Case Gambar 1 bisa dilihat melalui tabel 2 yang menjelaskan deskripsi aktor yang terlibat dalam sistem beserta wewenang yang dilakukan oleh aktor.

Tabel 3 menjelaskan deskripsi tentang enam kegiatan yang dapat dilakukan oleh aktor yang terlibat pada sistem portal dimana kegiatannya tergambar pada use case diagram gambar 1.

Tabel 2. Wewenang Aktor

\begin{tabular}{ccll}
\hline No & Aktor & \multicolumn{1}{c}{ Deskripsi } & Wewenang \\
\hline $\mathbf{1}$ & Admin & Yang bertugas & • Input data \\
& & dan memiliki & baru \\
& & akses dalam & • Mengubah \\
& & merekayasa data & data \\
& & dalam database & - Menghapus \\
& & sistem portal. & data \\
& & - Melihat data \\
& & - Mencetak \\
& & - data \\
\hline $\mathbf{2}$ & Pengguna & Orang yang & - Melihat data \\
& & memiliki akses & - Mencetak \\
& & untuk melihat & data \\
& & dan mencetak & \\
& & data dari sistem. & \\
& &
\end{tabular}

Tabel 3. Deskripsi Use Case

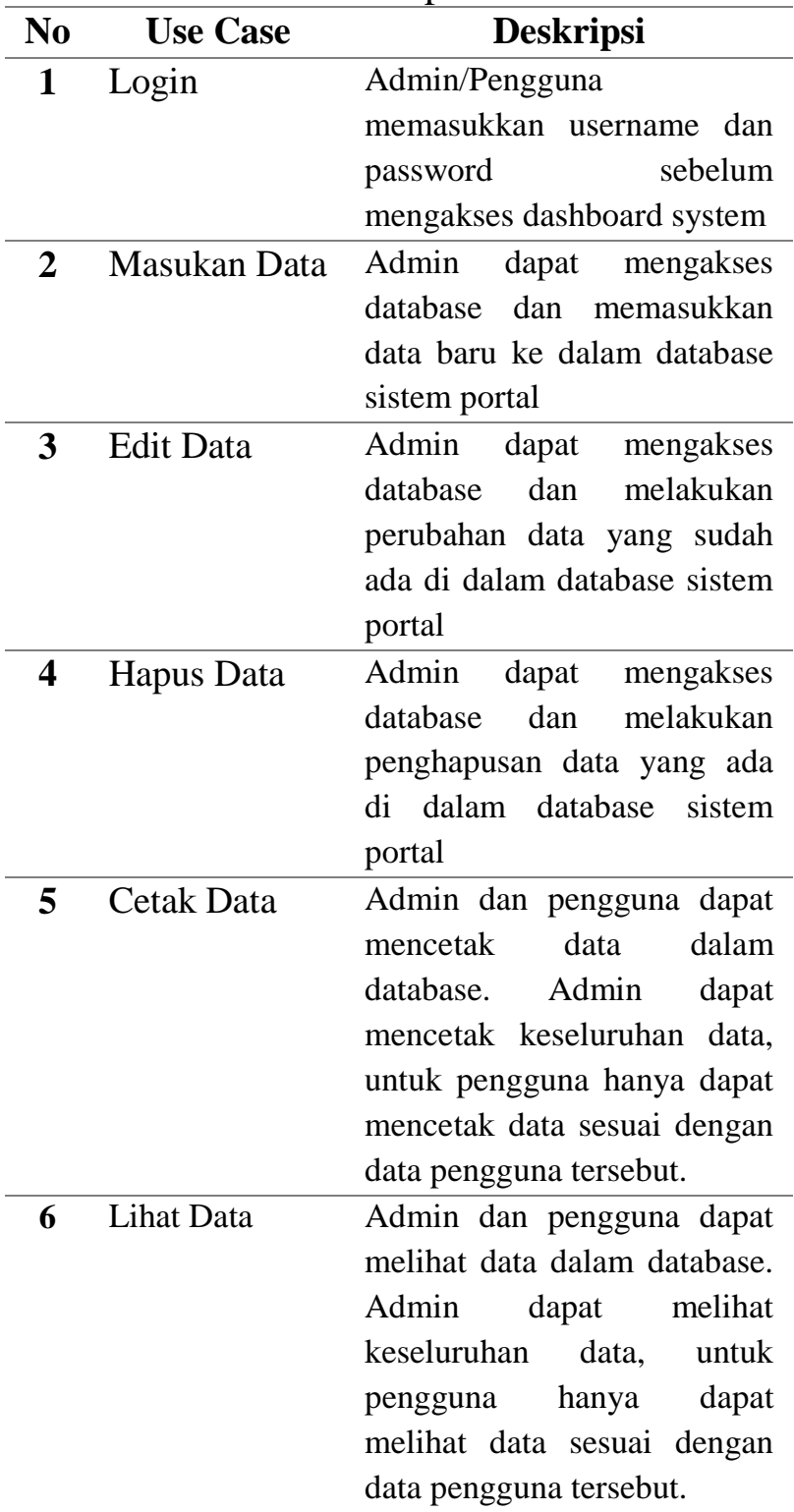




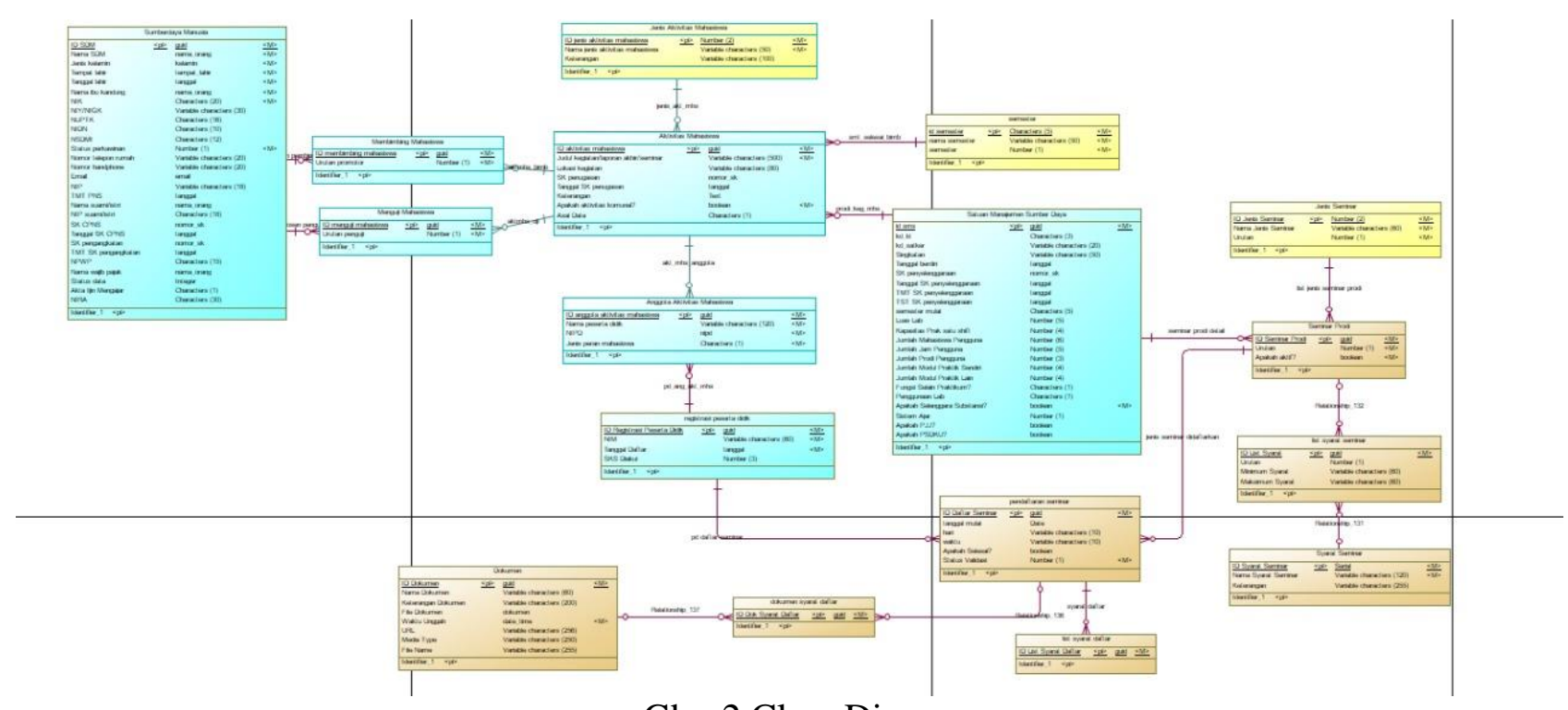

Gbr. 2 Class Diagram

Class diagram menggambarkan sebuah sistem dengan memberikan definisi dari setiap kelas yang dirancang dalam pembuatan sistem. Class diagram ini dibuat untuk menyelaraskan antara dokumentasi pada saat desain dengan sistem perangkat lunak yang akan dibuat. Class diagram seperti yang tampil pada gambar 2 .

Struktur navigasi portal adalah urutan alur informasi yang ditampilkan untuk menggambarkan secara garis besar sususan yang ada pada portal secara keseluruhan. Dalam sebuah pembangunan sistem portal diperlukan struktur navigasi sebagai bentuk penggambaran dari halaman apa saja yang tersedia di dalam portal. Gambar 3 memperlihatkan rancangan struktur navigasi sederhana yang akan diterapkan pada portal.

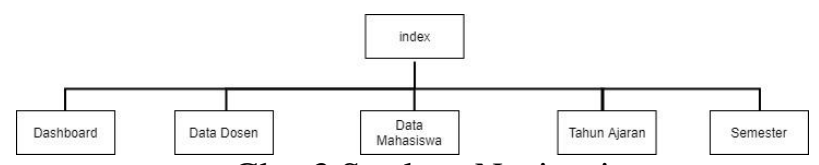

Gbr. 3 Struktur Navigasi

\section{HASIL DAN PEMBAHASAN}

\section{A. Pembangunan Antarmuka}

Berdasarkan perancangan maka dibangunlah antarmuka dari aplikasi sistem portal prodi. Antarmuka sistem meliputi antara lain bagian login, bagian daftar akun dan bagian yang secara umum menampilkan data.
Tampilan dari antarmuka portal dapat dilihat pada gambar 4.1 dan gambar 4.2. Halaman daftar akun menampilkan form pengisian yang dapat diisi oleh email user yang harus diisi sesuai dengan format email yang benar. Contoh namaemail@namaweb.com. Kemudian pengguna harus menekan tombol "Daftar Akun" untuk melakukan registrasi, yang kemudian password akan dikirimkan melalui email yang di daftarkan sebelumnya.

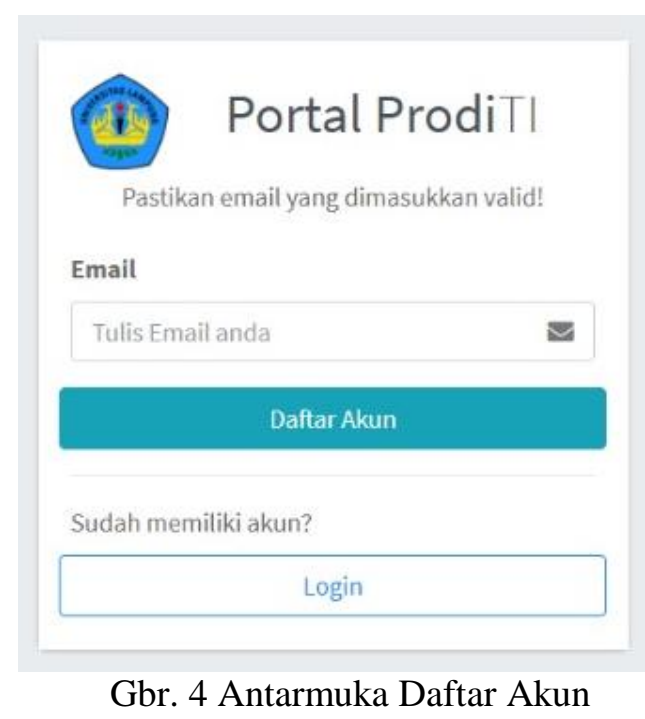

Sedangkan pada halaman login dapat dilihat dua form isian. Yaitu form Username dan Password. Pada Username pengguna harus memasukkan email yang sudah terdaftar pada sistem, lalu menginput password yang sesuai dan kemudian menekan 
tombol "sign in" untuk masuk ke dalam sistem portal.

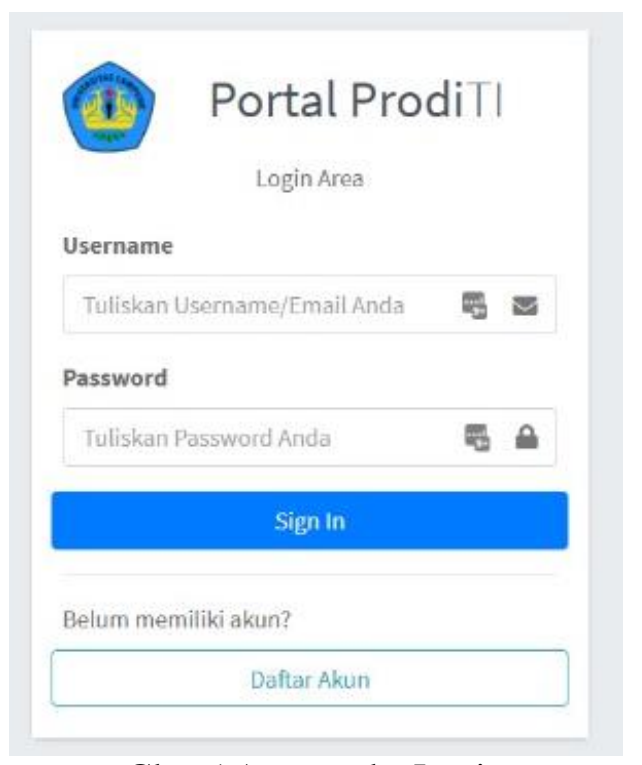

Gbr. 5 Antarmuka Login

Ada dua bagian pada halaman yang terlihat oleh pengguna. Bagian kiri sebagai navigasi portal dan kanan yang menggunakan sebagian besar halaman adalah tampilan isi dari halaman yang dituju berisikan tampilan data. Untuk bisa berpindah ke halaman yang lain bisa dengan memilih link pada navigasi disebelah kiri dan datanya akan ditampilkan secara detail di halaman bagian sebelah kanan. Ada enam halaman utama yang bisa dilihat yaitu Dashboard, Dosen, Mahasiswa, Tahun Ajaran dan Semester.

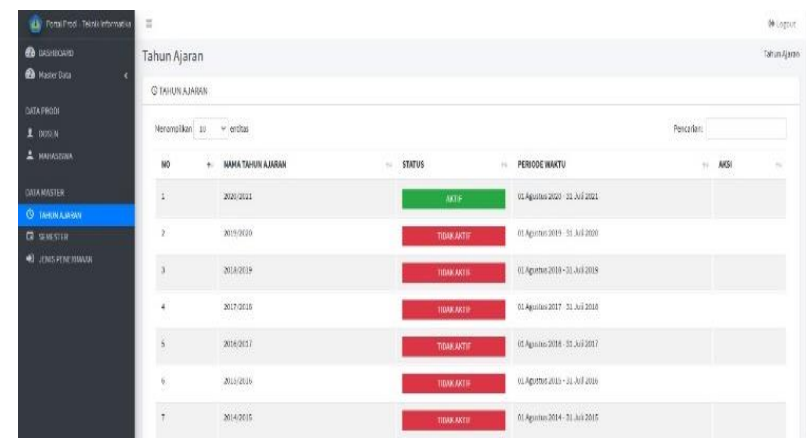

Gbr. 6 Tampilan Halaman Tahun Ajaran

Pada gambar 6 terlihat tampilan dari halaman bagian tahun ajaran pada portal. Sedangkan pada gambar 7 menampilkan halaman semester. Kedua halaman ini menjadi salah satu contoh yang menjadi tampilan dasar berbasiskan web dari portal program studi.

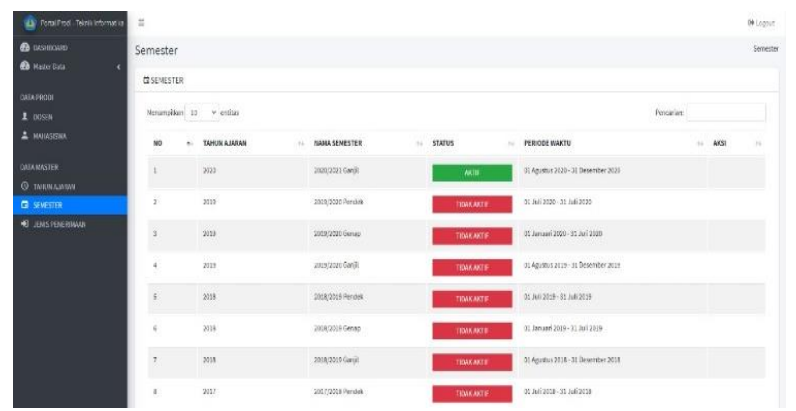

Gbr. 7 Tampilan Halaman Semester

Tampilan dari antar muka portal ini dibuat berdasarkan kebutuhan dari rancangan portal yang kemudian setiap halaman akan saling terhubung sesuai dengan rencana pada struktur navigasi portal yang diperlihatkan pada gambar 3. Kemudian hasil rancangan ini harus melalui proses selanjutnya yaitu pengujian untuk mengetahui apakah rancangan dan hasil pembangunan portal sudah sesuai dengan yang diharapkan.

\section{B. Pengujian}

Setelah implementasi pembangunan portal sesuai dengan kebutuhan dan desain, maka dibutuhkan pengujian dari sistem yang sudah dibangun untuk mengetahui kesuaian antara implementasi dengan rencana dan desain. Pada penelitian kami di fase pengujian akan menerapkan penggunaan metode pengujian blackbox.

Metode ini digunakan untuk mengetahui apakah pada sistem portal yang sudah dibangun ini memiliki kesalahan maupun bug pada fungsinya saat dijalankan

Pengujian pada halaman login dengan melibatkan dua form isian berupa email dan password serta satu tombol untuk login. Hasil dari kegiatan pengujian secara detail dapat dilihat di tabel 4 tentang pengujian halaman login.

Pengujian pada halaman daftar dilakukan dengan melakukan aktifitas pada penginputan di form pengisian dan tombol. Hasil uji diperlihatkan pada rencana dan pengamatan tabel 5 tentang pengujian halaman daftar. 
Tabel 4. Pengujuan Halaman Login

\section{Hasil Uji}

\begin{tabular}{llll}
\hline $\begin{array}{l}\text { Data } \\
\text { Masukan }\end{array}$ & Rencana & Pengamatan & Hasil \\
\hline Akses & Tampil & Antar muka & \\
Sistem & form login & pada halaman & Sesuai \\
& yang terdiri & login & \\
& dari & menampilkan & \\
& username & form login & \\
& dan & yang terdiri & \\
& password. & dari username & \\
& Serta & dan password. \\
tombol & Serta tombol \\
& Login dan & Login dan link \\
& link daftar. & daftar. \\
& & \\
\hline
\end{tabular}

Tabel 5. Pengujian Halaman Daftar

\begin{tabular}{|c|c|c|c|}
\hline \multicolumn{4}{|c|}{ Hasil Uji } \\
\hline $\begin{array}{l}\text { Data } \\
\text { Masukan }\end{array}$ & Rencana & Pengamatan & Hasil \\
\hline $\begin{array}{l}\text { Akses } \\
\text { Sistem }\end{array}$ & $\begin{array}{l}\text { Tampil form } \\
\text { daftar yang } \\
\text { terdiri dari } \\
\text { username/email. } \\
\text { Serta tombol } \\
\text { daftar dan link } \\
\text { menuju halaman } \\
\text { login. }\end{array}$ & $\begin{array}{l}\text { Antar muka } \\
\text { pada halaman } \\
\text { daftar } \\
\text { menampilkan } \\
\text { form login yang } \\
\text { terdiri dari } \\
\text { terdiri dari } \\
\text { username/email. } \\
\text { Serta tombol } \\
\text { daftar dan link } \\
\text { menuju halaman } \\
\text { login. }\end{array}$ & Sesuai \\
\hline
\end{tabular}

Pengujian pada navigasi portal juga dilakukan untuk melihat kesesuaian rancangan navigasi dengan hasil rancanga bangun portal. Tombol navigasi yang diakses terdapat disisi dashboard dari halaman portal. Tabel 6 menampilkan tombol mana saja yang diuji.
Tabel 6. Pengujian Navigasi Portal

\section{Hasil Uji}

\begin{tabular}{|c|c|c|c|}
\hline $\begin{array}{l}\text { Data } \\
\text { Masukan }\end{array}$ & Rencana & Pengamatan & Hasil \\
\hline $\begin{array}{l}\text { Tombol } \\
\text { Dashboard }\end{array}$ & $\begin{array}{l}\text { Redirect ke } \\
\text { halaman } \\
\text { Dashboard } \\
\text { atau index } \\
\text { halaman awal. }\end{array}$ & $\begin{array}{l}\text { Antarmuka } \\
\text { redirect ke } \\
\text { halaman } \\
\text { Dashboard } \\
\text { atau index } \\
\text { halaman awal. }\end{array}$ & Sesuai \\
\hline $\begin{array}{l}\text { Tombol } \\
\text { Dosen }\end{array}$ & $\begin{array}{l}\text { Redirect ke } \\
\text { halaman } \\
\text { Dosen. } \\
\text { Menampilkan } \\
\text { data dosen } \\
\text { yang sudah di } \\
\text { input ke } \\
\text { database }\end{array}$ & $\begin{array}{l}\text { Antarmuka } \\
\text { redirect ke } \\
\text { halaman } \\
\text { Dosen. } \\
\text { Menampilkan } \\
\text { data dosen } \\
\text { yang sudah di } \\
\text { input ke } \\
\text { database }\end{array}$ & Sesuai \\
\hline $\begin{array}{l}\text { Tombol } \\
\text { Mahasiswa }\end{array}$ & $\begin{array}{l}\text { Redirect ke } \\
\text { halaman } \\
\text { Mahasiswa. } \\
\text { Menampilkan } \\
\text { data } \\
\text { mahasiswa } \\
\text { yang sudah di } \\
\text { input ke } \\
\text { database }\end{array}$ & $\begin{array}{l}\text { Antarmuka } \\
\text { redirect ke } \\
\text { halaman } \\
\text { Mahasiswa. } \\
\text { Menampilkan } \\
\text { data } \\
\text { Mahasiswa } \\
\text { yang sudah di } \\
\text { input ke } \\
\text { database }\end{array}$ & Sesuai \\
\hline $\begin{array}{l}\text { Tombol } \\
\text { Tahun } \\
\text { Ajaran }\end{array}$ & $\begin{array}{l}\text { Redirect ke } \\
\text { halaman } \\
\text { Tahun Ajaran. } \\
\text { Menampilkan } \\
\text { data Tahun } \\
\text { Ajaran yang } \\
\text { aktif dan tidak } \\
\text { aktif }\end{array}$ & $\begin{array}{l}\text { Antarmuka } \\
\text { redirect ke } \\
\text { halaman } \\
\text { Tahun Ajaran. } \\
\text { Menampilkan } \\
\text { data Tahun } \\
\text { Ajaran yang } \\
\text { aktif dan tidak } \\
\text { aktif }\end{array}$ & Sesuai \\
\hline $\begin{array}{l}\text { Tombol } \\
\text { Semester }\end{array}$ & $\begin{array}{l}\text { Redirect ke } \\
\text { halaman } \\
\text { Semester. } \\
\text { Menampilkan } \\
\text { data Semester } \\
\text { yang aktif. }\end{array}$ & $\begin{array}{l}\text { Antarmuka } \\
\text { redirect ke } \\
\text { halaman } \\
\text { Semester. } \\
\text { Menampilkan } \\
\text { data Semester. }\end{array}$ & Sesuai \\
\hline
\end{tabular}




\section{KESIMPULAN}

Perancangan Sistem Portal Program Studi Dengan Menggunakan Framework Laravel dan Database PostgreSQL telah selesai dibuat dan data di dalam portal yang dibuat telah tampil dan sesuai dengan perencanaan. Penggunaan Framewok Laravel pada Pembuatan Portal Program Studi dapat memudahkan pengembangan sistem dan juga dalam pengelolaan karena pada framework Laravel terdapat syntax memiliki fungsi yang lebih baik, lebih bersih dan juga library yang banyak. Sehingga secara fungsi pada penggunaannya mudah untuk diaplikasikan dan juga mempercepat pembangunan sistem portal program studi. Penelitian kali ini menampilkan hasil pengujian sistem dengan penggunaan metode Black-Box testing didapatkan bahwa fungsi yang dibuat pada modul artikel ini sudah sesuai dengan kebutuhan sistem.

Pengembangan selanjutnya yang dapat dilakukan pada sisi konten dari portal yang bisa saling terintegrasi dengan beberapa sistem informasi yang ada pada program studi, seperti student service corner program studi.

\section{UCAPAN TERIMA KASIH}

Penulis sampaikan rasa terima kasih yang tulus kepada semua pihak yang telah berkontribusi dalam penelitian ini, dan juga saran yang diberikan untuk penyelesaian penelitan ini. Terima kasih kepada Fakultas Teknik Universitas Lampung yang telah memberikan hibah penelitian sehingga kami dapat menyelesaikan penelitian ini dengan baik walaupun masih banyak kekurangan.

\section{REFERENSI}

[1] Bramantia, A. C, Analisis Dan Perancangan Web Portal Sistem Informasi Akademik Beberapa Perguruan Tinggi Menggunakan Basis Data Terdistribusi Pada Suatu Yayasan, Fakt. Exacta, vol. 10, no. 4, pp. 362-372, doi: http://dx.doi.org/10.30998/faktorexacta.v10i 4.1352, 2017.

[2] Budhija, Er. N. and Er. S. Pal Ahuja, Study of Software Process Model Selection, Int. J. Adv. Res. Comput. Sci., vol. 2, no. 6, pp.
279-282,

doi:

https://doi.org/10.26483/ijarcs.v2i6.898, 2011.

[3] Havlicek, J. and Z. Havlicek, A Portal with Decision Support System for Agribusiness, J. Decis. Syst., vol. 12, no. 2, pp. 177-191, doi: https://doi.org/10.3166/jds.12.177-191, 2012.

[4] Luthfi, F, Penggunaan Framework Laravel Dalam Rancang Bangun Modul Back-End Artikel Website Bisnisbisnis.ID, J. Inform. Sunan Kalijaga, vol. 2, no. 1, pp. 34-41, doi: http://dx.doi.org/10.14421/jiska.2017.21-05, 2017.

[5] Munawar, Pemodelan Visual dengan UML, 1st ed., Yogyakarta: Graha Ilmu, 2015.

[6] Nilmada, M, Pembuatan Situs Portal Berita Seputar Kampus Universitas Gunadarma Menggunakan Framework PGP Codeigniter dan Basisdata Mysql, Gunadarma, 2008.

[7] Oktaviani, D, Rancang Bangun Portal Seminar Nasional Berbasis Web, Seminar Nasional Telekomununikasi Dan Informasi, pp. 297-305, 2018.

[8] Parkar, V. V. et all, Utilization of Laravel Framework for Development of Web Based Recruitment Tool, IOSR J. Comput. Eng., vol. 1, no. 1, pp. 36-41, 2018.

[9] Pathak, A. K. et all, FisOmics: A portal of fish genomic resources, Genomics, vol. 111, no. 6, pp. 1923-1928, 2019.

[10] Rosalina, A. et all, Pengujian Black Box pada Sistem Informasi Penjualan HI Shoe Store Menggunakan Teknik Equivalence Partitions, J. Inform. Universitas Pamulang, vol. 5, no. 1, pp. 26-29, 2020.

[11] Santiari, N. P. L. et all, Aplikasi Reservasi Lapangan Futsal dengan Metode Black Box Testing Menggunakan Teknik Boundary Value Analysis, J. Inform. Universitas Pamulang, vol. 5, no. 3, pp. 321-327, 2020.

[12] Santoso, A. K, Perancangan dan Realisasi Web Portal Jurusan Teknik Elektro Universitas Kristen Maranatha, Unika Maranatha, 2016.

[13] Turban, E. and J. E. Aronson, Decision Support System and Intelligent System, 7th ed., Prentice Hall, 1998. 